\title{
Gender differences in family business management: do they really exist?
}

\section{Shaike Marom*}

School of Management, Western Galilee College, P.O. Box 2125 Acre 24121, Israel

Email: shaikem@wgalil.ac.il

*Corresponding author

\section{Robert N. Lussier}

Department of Business Management, Springfield College, Springfield, MA 01109, USA

Email: rlussier@springfieldcollege.edu

\section{Matthew C. Sonfield}

The Robert F. Dall Distinguished, 229 Weller Hall, Zarb School of Business, Department of Management \& Entrepreneurship, Hofstra University, Hempstead, NY 11549-1340, USA

Email: Matthew.C.Sonfield@Hofstra.edu

\begin{abstract}
Research investigating whether there are gender differences in the management of businesses has produced mixed results. This study investigated gender differences within the family business sector. Empirical inquiry was based on data collected from 210 small family businesses in South America. Results indicate no significant gender differences in managerial activities and characteristics of the surveyed family businesses. Analysis of the results infers that such gender differences may be culture dependent. Theoretical and practical regional development implications for family business ownermanagers, educators, consultants, and public policy and suggestions for further family business research are presented.
\end{abstract}

Keywords: family business; gender difference; SME management; social role theory.

Reference to this paper should be made as follows: Marom, S., Lussier, R.N. and Sonfield, M.C. (2020) 'Gender differences in family business management: do they really exist?', Int. J. Family Business and Regional Development, Vol. 1, No. 1, pp.25-45. 
Biographical notes: Shaike Marom heads the concentration in management of small and medium-sized enterprises at the Sir Harry Solomon School of Management, at the Western Galilee College. He is an expert on entrepreneurship, innovation management and sustainability. Having extensive experience in corporate management and international business, he is called upon regularly to serve as consultant for the private sector with particular emphasise on technology and start-up endeavours.

Robert N. Lussier is a Professor of Management at Springfield College, USA. He is the author of more than 440 publications including AEJ, ET\&P, FBR, JME, JSBED, JSBM, JSBS and others. More than one million people globally have used his textbooks: Human Relations 10e (Irwin/McGraw-Hill); Management 7e and Human Resource Management 2e and Fundaments of HRM 1e (Sage); Leadership 6e and Small Business 3e (South-Western/Cengage); Entrepreneurship 3e and Business, Society and Government 2e (Routledge) and Research Methods and Statistics (Waveland); plus, Publish Don't Perish: Top Secrets to Get Published. Lussier is also a keynote speaker, visit http://www.publishdonotperish.com.

Matthew C. Sonfield is the Robert F. Dall Distinguished Professor in Business at the Zarb School of Business, Hofstra University, New York. He received his $\mathrm{AB}, \mathrm{MBA}$, and $\mathrm{PhD}$ from Cornell University, Harvard University, and New York University. He has over 400 publications to his name in a wide variety of academic and practitioner journals.

This paper is a revised and expanded version of a paper entitled 'South American family businesses: a gender-based analysis' presented at Annual National Conference of the Small Business Institute 2013, St. Pete Beach, Florida, 14-16 February 2013.

\section{Introduction}

According to common comprehension there are differences between men and women related to various aspects, and drawing on multiple knowledge areas (Eagly, 2013). Such differences include sex differences based on biology and physiology; and gender differences drawing on knowledge from a variety of fields including anthropology, sociology, cognitive psychology and social psychology (Costa et al., 2001; Eagly, 2013; Eagly et al., 2000). Gender differences are hypothesised to develop as a result of both biological differences as well as social aspects related to values and status and roles within society, which influence the development of gender identity and attributes (Eagly and Wood, 1999; Maccoby and Jacklin, 1974). Possible gender impacts could relate to the management of large and small firms and family businesses, and range from firm performance to implications on recruitment, job suitability and other issues within this field. Such understanding of gender differences and their impact have the potential to serve individuals, firms and society - in the aspiration for happiness, self-actualisation, and better business performance (Eagly and Heilman, 2016).

Over several decades of gender issue research, there have been mixed results and a change in the findings (Sonfield and Lussier, 2009). Specifically, research during most of the $20^{\text {th }}$ century, commonly resulted in findings that support significant impact from gender differences in management. However, during the last decade it has been more 
common that findings did not support a significant impact on management issues due to gender differences (Collins-Dodd et al., 2004; Sonfield and Lussier, 2009; Sonfield et al., 2001; Watson, 2002). Whether one of those opposing views holds true, plays an important role in understanding how gender issues impact management, and eventually firm performance. Moreover, a significant part of recent research has been based on qualitative rather than quantitative methods, with few family business studies (Danes and Olson, 2003; Jimenez, 2009). Therefore, there has been a call for further research on women in the family firm, including their impact on leadership management and other aspects related to running of the family firm (Jimenez, 2009).

Family businesses constitute a highly important component of most countries' economies, constituting around $80 \%$ of all businesses, and contributing around $60 \%$ of GDPs (Astrachan and Shanker, 2003; Dennis, 2003; Kellermanns et al., 2008; Poza and Daugherty, 2013). In the USA, an estimated $80 \%$ to $90 \%$ of businesses are family businesses (Carsrud, 1994; Kets de Vries, 1993; Poza, 2007) and, on average, have higher annual sales than non-family businesses of similar size (Astrachan and Shanker, 2003; Bellet et al., 1995; McCann et al., 1997; Morris et al., 1997). Data from most other countries support the importance of family businesses, often with even higher percentages (Morck and Yeung, 2003; Rottenberg, 2002). Family businesses are particularly important in South America, where $85 \%$ of companies are family-owned businesses, creating $60 \%$ of Latin America's GDP, and employing $70 \%$ of the workforce in the region (Al-Dajani et al., 2014; EY, 2014; Poza and Daugherty, 2013). Although gender and family business are important areas of research, there have been relatively few studies investigating the role of gender in family business (Al-Dajani et al., 2014).

This quantitative study examined a variety of important management activities, styles, and practices of family firms, while testing for variations due to the impact from gender difference, including management style, decision-making, use of outside advisors, family involvement in decisions and level of family conflict; with a sample of 210 family businesses in South America. Findings support the hypothesis that female participation in the management of family businesses does not have a significant impact on the business. Our research makes a theoretical contribution to the mixed results in the currently limited body of literature dealing with gender issues in family business (Danes et al., 2005; Fasci and Valdez, 1998; Renzulli et al., 2000; Watson, 2001; 2002), using a quantitative research design. Thus, the research question is: What is the relationship between the gender of owner-managers of family businesses and the ways in which these businesses are run in terms of management style? Theoretical and practical implications for the family business field are presented.

The remainder of the article is structured as follows: The next section presents an overview on some theories and models that predicted gender differences that apply to the management domain. We then explain the theoretical framework for the research and hypotheses. This is followed by the methods, research design, and analysis of results. Finally, we discuss the findings and their theoretical and practical implications, with limitations and suggestions for further research.

\section{Gender differences in management}

Gender differentiation is an important element that affects many aspects in life including management within the business sector. The research literature has developed several 
concepts and theories, including psychological, biological, and sociostructural fields, to explain the development of differences between men and women (Bussey and Bandura, 1999). Most concepts on gender difference assume that they are the result of evolutionary development in which each sex has faced different roles and problems to cope with (Buss, 1997; Buss and Schmitt, 2011; Bussey and Bandura, 1999). These social roles provided women with psychological and emotional benefits to enrich their interpersonal skills, while creating less enriched in other areas (Ruderman et al., 2002). In this section we discuss: social role theory, hunter-gatherer hypothesis, leadership and management style, other business-related gender differences, and cultural variability in gender differences.

\subsection{Social role theory}

Social role theory suggests that some behavioural differences between men and women are the result of their social roles, at home and other places, in response to societal norms and expectations (Eagly, 1987; Bussey and Bandura, 1999). Such roles may include parent and spouse roles, household and community engagement, as well as occupation. Over time, such stereotype roles have developed into behavioural differences that are passed on along generations. Thus, women and men are expected to develop different capabilities in areas in which they have faced different challenges over human evolutionary period (Bussey and Bandura, 1999; Schmitt et al., 2008). As a result, women developed traits that manifest communal behaviour built on tendency to be expressive, friendly, affectionate, helpful, sympathetic, and more cooperative and collaborative (Eagly and Johannesen-Schmidt, 2001; Eagly and Wood, 1991; Eagly et al., 2000). Those feminine communal attributes are in contrast to male behavioural attributes that are agentic in nature (Eagly and Johannesen-Schmidt, 2001). The necessity to cope with multiple demands from the environment has created positive outcomes manifested in psychological attributes, such as expansion of personal skills to handle multiple roles. Such enhanced personal resources and skills serve also for unique female characteristics within the management domain, including leadership and management style, handling multiple tasks, risk taking and social capital; as described below (Eagly and Johannesen-Schmidt, 2001).

\subsection{Hunter-gatherer hypothesis}

The hunter-gatherer hypothesis (H-G hypothesis) leads to a similar understanding about gender differences as the social role theory. However, from a biological perspective, rather than from social science perspective, the $\mathrm{H}-\mathrm{G}$ hypothesis assumes that the differences between female and male are the result of 'natural selection' whereby organisms tend to better adapt to their environment for survival. Accordingly, men who were tasked with hunting, developed better spatial abilities as well as being more prone to take risks and to seek social dominance; whereas women developed gathering-related skills, being more cautious and having communal behaviour (Buss, 1997; Eals and Silverman, 1994). For example, while men needed to concentrate on a single task of hunting, women who stayed behind needed to develop the capability to handle simultaneously several tasks (Eagly and Johannesen-Schmidt, 2001; Silverman et al., 2007). 


\subsection{Leadership and management style}

As derived from the above mentioned theories, and the specific attributes and skills that women have developed, scholars identified several gender differences in leadership and management style (Eagly and Johannesen-Schmidt, 2001, Vadnjal and Zupan, 2009). First, women tend to use a democratic management style, which allow subordinates to participate in decision making, drawing on their communal attributes of cooperative and collaborative (Sonfield and Lussier, 2012). Second, women tend to use an interpersonally oriented leadership style, rather than a task-oriented style, following their attitude to be affectionate, helpful and sympathetic. Third, women are said to have a transformational leadership style, which is built on trust between leader and followers, rather than transactional style that utilises instruction and reward systems (Eagly and Carli, 2003; Eagly and Johannesen-Schmidt, 2001; Vadnjal and Zupan, 2009). However, other scholars have advanced a different view, asserting that gender differences in management are not universal but rather depend on context (Eagly and Carli, 2003; Eagly and Carli, 2007; Powell, 1990).

\subsection{Other business-related gender differences}

Several other gender differences, in relation to the management domain, grounded in the above mentioned theories, have been suggested and researched, including:

- Conflict-handling style: as an outcome of their communal attributes, women are more likely to use an integrating style of conflict-management, showing high level of concerns for others and building understanding among the parties involved (Brewer et al., 2002; Havenga, 2008).

- Risk taking: there is research supporting the hypothesis that women are more risk adverse (Collerette and Aubry, 1990; DiBerardinis et al., 1984; Mínguez-Vera and Martin, 2011). This is particularly important within decision-making in that women managers are less risk seeking than men (Powell and Ansic, 1997). This could be an outcome of their social role to be responsible for the safety and well-being of their home and community (Filipsson et al., 2014; Powell and Ansic, 1997).

- Multitasking: women have been found to better cope and perform in multitasking situations. This it attributed to their social role that required them to perform a greater number of activities during the day (Mantyla, 2013; Ren et al., 2009).

- Social capital: significant gender differences were found with regard to social capital, which is defined as investment and use of social relations for expected returns (Westermann et al., 2005). It was found that women have larger and greater diversity in their social networks than men (Lin, 2000). This could be attributed to their social role that requires more collaboration and solidarity (Westermann et al., 2005). This could result in gender differences in management of family businesses. For example, female owners of small businesses were reported to be more flexible in recruiting non-family employees, and tend to be less formal with requirements from candidates (Kotey and Sheridan, 2001). 
Moreover, women social capital contributes to improve the strength of family relationships, which in turn enhances the family social capital. Such family social capital, which has been identified as a distinguishing factor between family businesses from nonfamily businesses, contributes to improved performance and revenues of family businesses (Danes et al., 2009; Sorenson and Bierman, 2009).

\subsection{Cultural variability in gender differences}

Because gender differences are the results of different social roles and challenges, it has been assumed that when women and men will be faced with similar roles, gender differences will tend to cease to exist (Eagly and Wood, 1999; Wood and Eagly, 2002). Thus, it is assumed that in modern societies, where higher gender equality and opportunities exist, both men and women will tend to face similar roles, thereby eroding gender differences.

It has been asserted that the size of gender differences in personality varies among cultures (Schmitt et al., 2008). According to Schmitt et al. (2008), during the last two decades, the personality gap between men and women is shrinking in traditional societies. However, this gap is growing in modern societies. With regard to modern societies of the western nations, this change is counterintuitive and is going in the wrong direction relative to evolutionary psychologists' school of thought. Evolutionary psychology scholars were expecting that the diminishing of traditional social roles will result in fewer differences between genders. The growing gap in gender personality, in modern wealthy society, has been attributed to higher gender equality that reduced external barriers, making room for revival of ancient internal differences. However, the same study (Schmitt et al., 2008) reported that gender personality differences are getting smaller in traditional cultures.

\section{Foundations in prior gender in family business research}

\subsection{Family businesses}

Family businesses have been recognised as a major component and growth engine of economies worldwide (Astrachan and Shanker, 2003). In the USA, family businesses constitute about $80 \%$ to $90 \%$ of the total incorporated firms, mounting to around 17 million businesses (Poza and Daugherty, 2013). Although many of the family businesses are small in size, overall this sector contributes about $30 \%$ of the gross domestic product and about $85 \%$ of jobs in the private sector (Astrachan and Shanker, 2003; Poza and Daugherty, 2013). It is estimated that family-controlled businesses constitute one-third of Fortune 500 firms (Carsrud, 1994; Poza and Daugherty, 2013).

Much effort has been invested in creating accurate and practical definitions for family businesses, yet, there is no single accepted universal definition of 'family business' (Astrachan and Shanker, 2003; Kraus et al., 2011; Sharma et al., 2012). Some definitions focus on their composition in terms of the number of family members involved, others focus on the degree of family control and involvement in the management operations of the firm, yet others consider the owners' perceptions and the potential to sustain the business across generations (Miller et al., 2007; Sciascia and Mazzola, 2008). This study combined ownership, involvement in operations, and perception for its definition of 
'family business', with the third criterion being the final determinant. In this study, a business has family ownership and involvement in operations, as variables, and it also has been considered a 'family business' based on the respondent perception as a test of reliability, indicated in the returned questionnaires. All respondents indicated that they are a family business.

\subsection{Gender differences in management}

A sizable body of literature with a focus on women in management has developed over the last four decades (Bennett and Dann, 2000; Carter et al., 1997; Chaganti and Parasuraman, 1996; Powell and Ansic, 1997; Wagner, 2007). One of the main focus areas has been the research on gender differences in management, combining knowledge from the social and business domains (Sonfield and Lussier, 2009). The growing interest in research on gender differences in management was inspired by several realities. First, the share of jobs held by women has been growing significantly over the years, reaching to above $40 \%$ in the USA (Bureau of Labor Statistics, 2015). Second, the share of management positions held by women has also been growing steadily. Finally, the will to cope with the fact that women encounter a glass ceiling or barrier to advancement into senior management positions although they are equally capable or even may be superior under certain circumstances (Adams and Funk, 2012; Liff and Ward, 2001).

Earlier studies found several gender-related differences, suggesting that women managers were more cautious and less aggressive than were male managers (Powell and Ansic, 1997). However, more recent research suggested that there are no significant gender differences in management style (Collins-Dodd et al., 2004; Sonfield et al., 2001; Watson, 2002).

\subsection{Women in family business}

The growing interest in women family-member managers is based on their increased proportion in family businesses (Jimenez, 2009; Smith, 2007). It is estimated that women compose $22 \%$ of the average family business top management team globally, and own more than 33\% of all North American family businesses (Astrachan, 2002; EY, 2015). Studies on women in family firms have tended to investigate issues of women's roles in family firms, obstacles due to social positions, family relationships, professional career, leadership style, and succession (Cole, 1997; Danes et al., 2005; Danes et al., 2007; Harveston et al., 1997; Heinonen and Stenholm, 2011; Jimenez, 2009; Nelton, 1998; Rowe and Hong, 2000; Vadnjal and Zupan, 2009). Other studies have focused on differences and similarities in managerial performance, with mixed results (Danes et al., 2005; Fasci and Valdez, 1998; Renzulli et al., 2000; Watson, 2001; 2002). However, most of the studies are conceptual rather than empirical (Danes and Olson, 2003; Jimenez, 2009; Vera and Dean, 2005). Thus, with conceptual mixed results, further empirical research is needed.

\section{South American family business context and literature review}

Since the 1990s, South America has experienced great economic development, with Argentina and Peru, and several other countries on the continent, having economic 
growth of over $8 \%$ per year, relying heavily on the exporting of goods. South American economic growth continued during most of the 2000s, however growth slowed down during the first half of the 2010s. This slowdown has been attributed to the global economic recession, low prices of oil and other natural resources, and China-led commodity decline. However, the IMF forecast for 2016 and on, expects the region economy to recover and expand by $0.8 \%$ in 2016 (IMF, 2015; The Economist, 2015; World Bank, 2015a; World Economic Forum, 2016). On this background and efforts by national economies to create economic growth the importance of family businesses stands out due to their large share in national GDP and ability to boost the economy (Astrachan and Shanker, 2003).

\subsection{Argentina}

Argentina, with a population of 43 million people, is the third largest economy in Latin America and in recent years the country has focused on economic development (The World Bank, 2016). It is a high-income economy that benefits from rich natural resources, a highly literate population rated as very in high human development, a strong agricultural sector, and a diversified industrial sector (UN HDR, 2015; World Bank, 2015b).

Family businesses in Argentina are of great economic importance as they constitute around $75 \%$ of all businesses in the country, provide about $70 \%$ of the private sector jobs, contribute around $50 \%$ of GNP and are involved in $95 \%$ of the local trade (Kaplun, 2001). Around 50,000 new small businesses are formed each year, and most of them, around $85 \%$, are founded by young people in their mid-twenties.

During the last two decades, there has been steady growth in the participation of women in the work force in Argentina, as a result of increased gender equality (World Economic Forum, 2014). However, there is still low participation of women in this sector. Only about 5\% of businesses are owned by women (Mancuso, 2009), and their firm-sizes have been found to be smaller than men owned businesses (Amin, 2011). Additionally, the labour productivity for female-owned businesses hase been found to be lower than for male owned firms (Amin, 2011).

In contrast to their importance, there have only been a few studies of family businesses in Argentina (Niethardt, 2007). Niethardt (2007) asserted that “...there are no significant statistical samplings that have been conducted on family businesses in the last twenty years...", and D'Annunzio and Rabago (2007) and Rábago et al. (2009) concluded that there is a need for further family business research in Argentina.

\subsection{Peru}

Peru has been one of the fastest growing economies in South America during the last decade. This has been the result of political change and moving away from socialism, together with structural reforms relating to various sectors. All this has led to an increase in GDP to around about \$192 billion in 2015 (World Bank, 2015c). The IMF (2016) report concluded that "Unlike most of its peers in Latin America, Peru's growth bounced back in 2015 largely due to increased production in primary sectors, as long-planned mining projects became active, and that growth is expected to rise further in 2016-2017".

Small and medium-sized businesses form about $95 \%$ of the total businesses in Peru, and $90 \%$ of all businesses are family owned (PWC, 2014). The increase in the number of 
family businesses is attributed to the liberalisation of the economy since the mid-1990s (Shimizu, 2004). The World Bank (2016) report on Peru shows great improvements in factors that contribute to the ease of doing business in Peru; including a shorter period to start a business, averaging 26 days. However, at the same time, most family businesses reported that they are still facing many barriers and difficulties, with particular emphasis on staff recruitment, competition and market conditions (PWC, 2014).

During the last decade, more women have joined family businesses, as well as starting their own businesses (APEC, 2016). This trend has been attributed to various factors including difficulty in finding jobs as well as the need to have more flexibility and control over the balance between family duties and work (APEC, 2016). In addition, family firms that are owned by women in Peru have been found to have similar labour productivity as well a similar average firm size as those owned by men (Amin, 2011).

\section{Research variables and hypotheses}

The above review of the literature comparing men and women owner-managers of family businesses indicates that this research has been limited. Moreover, such research has focused mainly on qualitative concepts such as role within the family business, but there has been little investigation of management characteristic variables. Moving in an empirical direction, this research is focused on quantitative inquiry of management characteristic variables related to family business. For that purpose, we have selected six managerial variables identified as important in the family business literature (Sonfield and Lussier, 2004). The support for difference between women and men, with regard to those variables, is derived from the theories and concepts presented earlier in this article, as depicted in Table 1.

Based on the literature supporting difference by gender, and stemming from Table 1, the following six hypotheses were developed:

H1: There is a positive relationship between the proportion of female-to-male owner-managers in a family business and the use of non-family-member managers.

$\mathrm{H} 2$ : There is a positive relationship between the proportion of female-to-male owner-managers in a family business and the use of a team-management decision-making style.

H3: There is a negative relationship between the proportion of female-to-male owner-managers in a family business and the occurrence of conflict and disagreements within the management team.

H4: There is a positive relationship between the proportion of female-to-male owner-managers in a family business and the use of outside advisors and professional services.

H5: There is a positive relationship between the proportion of female-to-male owner-managers in a family business and the time spent in strategic planning.

H6: There is a positive relationship between the proportion of female-to-male owner-managers in a family business and the use of an informal management style. 
Table 1 Managerial variables and supporting gender differences

\begin{tabular}{ll}
\hline Variable in hypothesis & \multicolumn{1}{c}{ Supporting theory/concept } \\
\hline & Social capital: women tend to recruit a higher \\
& percentage of non-family employees. \\
& Direction of relationship: positive relationship \\
Use of non-family-member managers & higher proportion of female-to-male in a family \\
& business will lead to more use of use of \\
& non-family-member managers. \\
& Participative decision making: allow subordinates to \\
& participate in decision making. \\
& Direction of relationship: positive relationship \\
& - higher proportion of female-to-male in a family \\
& business will lead to more use of use of a \\
& team-management decision-making style. \\
& Conflict-handling style: women's communal \\
Use of a team-management & attributes tend to lead to less occurrence of conflict. \\
decision-making style & Direction of relationship: negative relationship \\
& - higher proportion of female-to-male in a family \\
& business will lead to less occurrence of conflict. \\
& Cooperative and collaborative: women's communal \\
Occurrence of conflict and & attributes tend to value others' advice. \\
disagreements & Direction of relationship: positive relationship \\
& - higher proportion of female-to-male in a family \\
& business will lead to more use of outside advisors. \\
& Transformational leadership: women tend to ascribe \\
Formal versus informal management & a higher importance to long range planning \\
style & Direction of relationship: positive relationship \\
& - higher proportion of female-to-male in a family \\
& business will lead to spend more time in strategic \\
& planning. \\
& Leadership and management style: women's styles \\
& tend to be more cooperative, democratic, \\
& non-formal. \\
& Direction of relationship: positive relationship \\
& - higher proportion of female-to-male in a family \\
& business will lead to more use of an informal \\
& management style. \\
\hline & \\
\hline Time spent in strategic planning & \\
& \\
&
\end{tabular}

\section{Methods}

Survey research was designed to collect data for the study. The survey instrument was the previously published questionnaire used in the Sonfield and Lussier (2004) empirical study published in the top tier journal Family Business Review, providing support for its validity. The primary differences being that we included six of the eleven variable measures from their questionnaire; dropping the variables with less current support in the literature and relevance to gender issues, as per Table 1 and Table 4.

The data collection process used both mail and personal interviews. For the purpose of having a comprehensive and large sample of family firms, the data obtained from the two South American countries was combined. This provides more general and universal 
regional development findings rather than comparing family firms between the two countries. Accordingly, the data sets from Argentina and Peru were combined into one sample, as suggested by Lasagni (2012). A large combined sample serves also to obtain more meaningful and valid results (Lussier, 1997).

\subsection{Sample}

The same data collection procedure was used in both countries, with a combination of email and hand delivered. In Argentine and Peru, a national survey list of family businesses was obtained and all were contacted for data collection. To check reliability that the firm was in fact a family business, the respondents were asked if they were a family business, and all replied that they were family firms. In addition, data collectors personally knew that some of the firms were in fact family businesses, providing further support that the sample only includes family firms. Most family business owners completed the questionnaire on their own and returned it by email, while additional interviews were scheduled with non-respondents in order to complete the questionnaire and to increase the sample size and response rate.

In Argentina, 159 family businesses were contacted out of which 102 questionnaires were received; and in Peru 145 family businesses were contacted out of which 108 questionnaires were received. Thus, the total response rate was $70 \%$, yielding a sample size of 210 respondents. This is an excellent response rate and sample size in comparison to prior family business studies which had no sample, or less than 100 responses (Bird et al., 2002).

\subsection{Variables}

The dependent variable to test hypotheses 1 to 6 was the percentage of female family members involved in the management of the firm; and the mean percentage of women managers is $37 \%$. The independent variables are: (H1) the percentage of family to non-family managers. Hypotheses 2 to 6 were interval scales from 1 (does not describe our firm) to 7 (describes our firm). Note that full descriptions of these hypotheses variables were provided: (H2) full family involvement in decisions; (H3) level of family conflict; (H4) use of outside advisors and professional services; (H5) long-range thinking and decision-making; and (H6) management style.

\subsection{Statistical analysis}

Following the objectives of the research, regression statistical tests were run to determine if there is a correlational relationship between the percentage of women owner-managers in the family business and any of the six independent variables - as a model and individually. With regression, multiple correlations are run, but there is no implication of any of the variables having a causal effect on another variable (Lussier, 2011). Additionally, correlations were run between the independent variables, plus we ran the regression analysis with collinearity, the higher level diagnostics to ensure that multicollinearity was not problematic in the study. As discussed in the results section, we conclude that multicollinearity is not problematic. To further validate the regression results, stepwise regression was also run. 


\section{Results}

The descriptive statistics of the sample $(\mathrm{N}=210)$ are presented in Table 2 .

Results of the correlations between the independent variables are presented in Table 3. Results of hypothesis test by regression analysis are presented in Table 4.

The combined model of six variables is not significant, and none of the tests of the six hypotheses, based on the relationship between the percent of women and each of the independent variables, has statistically significant correlations. Therefore, the hypotheses are not supported as no relationships were found between the independent variables and the percent of women managers in the family business.

To further validate the regression results, stepwise regression was run. Results also support that there are no significant differences at any of the steps of the regression. Thus, as it is not common to report insignificant findings, especially when testing additional models, complete test results are not presented. Also, with a non-significant model at each step with an adjusted R-square of less than $1 \%$, reporting any changes in its $R$ value provide no valid additional insight.

The correlation matrix of the six independent variables presented in Table 3 indicated that five of the correlations are significant at the 0.05 level. However, the largest coefficient is only 0.268. With a large sample, results often indicate significant relationships with weak coefficients simply due to the sample size. The more robust multicollinearity test for all six independent variables had a tolerance of greater than 0.2 , with the lowest being 0.652. All six independent variables had a VIF of less than 0.4, with the highest being 1.35 . Therefore, multicollinearity should not be problematic within the variables (Lussier, 2011).

Table 2 Descriptive statistics

\begin{tabular}{lc}
\hline Variable & Statistics $(N=210)$ \\
\hline Country & $(\mathrm{n} / \%$ of N) \\
Peru & $108 / 51 \%$ \\
Argentina & $102 / 49 \%$ \\
& $($ mean $/$ s.d. $)$ \\
Percentage of Women & $37.22 / 25.70$ \\
Percentage of nonfamily managers & $7.82 / 20.27$ \\
Generation & $(\mathrm{n} / \%$ of N) \\
$1^{\text {st }}$ & $70 / 33 \%$ \\
$2^{\text {nd }}$ & $106 / 51 \%$ \\
$3^{\text {rd }}$ or more & $34 / 16 \%$ \\
Total N & $210 / 100 \%$ \\
& $(\mathrm{mean} / \mathrm{s.d})$. \\
Years in business & $20.52 / 18.53$ \\
Number of employees & $17.49 / 31.02$ \\
Industry & $(\mathrm{n} / \%$ of N) \\
Product & $90 / 43 \%$ \\
Service & $120 / 57 \%$ \\
Ownership & $(\mathrm{n} / \%$ of N) \\
Sole Proprietor & $131 / 62 \%$ \\
Partnership & $43 / 21 \%$ \\
Corporation & $36 / 17 \%$ \\
\hline
\end{tabular}


Table 3 Correlations

\begin{tabular}{lccccc}
\hline Independent variables & 1 & 2 & 3 & 4 & 5 \\
\hline 1. \% Non-family management & 1.00 & & & & \\
2. Family decision making style & 0.035 & 1.00 & & & \\
3. Family conflict & $0.154^{*}$ & 0.090 & 1.00 & & \\
4. Use outside advisors & $0.210^{*}$ & -0.103 & 0.067 & 1.00 & \\
5. Long-term planning & 0.080 & 0.107 & $0.190^{*}$ & $0.227^{*}$ & 1.00 \\
6. Management style & 0.017 & 0.036 & 0.089 & -0.026 & $0.268^{*}$ \\
\hline
\end{tabular}

Note: *Significant at the 0.05 level

Table 4 Regression analysis

\begin{tabular}{lcccc}
\hline \multicolumn{5}{c}{ Regression model } \\
\hline$R$ & $R^{2}$ & Adj. $R^{2}$ & $F$ & Sig \\
\hline 0.356 & 0.127 & 0.046 & 2.071 & 0.074 \\
\hline \multicolumn{5}{c}{ Correlation coefficients } \\
\hline Independent Variables & \multicolumn{3}{c}{ Beta } & Sig \\
\hline H1. \% Non-family management & -0.081 & 0.374 \\
H2. Family decision making style & 0.211 & 0.143 \\
H3. Family conflict & & 0.076 & 0.436 \\
H4. Use outside advisors & -0.012 & 0.873 \\
H5. Long-term planning & & 0.067 & 0.3925 \\
H6. Management style & 0.109 & 0.217 \\
(Constant) & & & 0.084 \\
\hline
\end{tabular}

\section{Discussion}

The results of this study did not support the hypothesis that there are gender differences in management of these South American family businesses. A higher percentage of women in the family businesses did not yield significant correlations to central attributes of the firms' operation, including management style, decision-making, use of outside advisors, family involvement in decision-making, and level of family conflict. This means that gender differences, stemming from the social role theory and the hunter-gatherer hypothesis and 'natural selection'; did not manifest in the management of these family businesses.

Thus, the results of this study refute much of the earlier research (Powell and Ansic, 1997), and earlier mixed results (Sonfield and Lussier, 2009), supporting the more recent trends in family business and entrepreneurial research that found few differences based on the gender of family owner-managers (Collins-Dodd et al., 2004; Sonfield et al., 2001; Watson, 2002). As stated by Reay and Whetten (2011), theory in family firms develops when studies are duplicated and where prior conflicting results are improved or modified by additional findings. Therefore, this study makes an important theoretical contribution to the theory of family business because it clarifies and modifies our comprehension of 
gender issues in family business by adding further support for the development of a theory supporting no significant differences between women and men in management of family businesses.

Possible explanation to not finding significant gender difference, in relation to family business, can come from their social and cultural background. Both countries are regarded as traditional society that is characterised by being male-dominated (UNDP, 2015). This can be attributed to the historical patriarchal society that existed for many centuries in many Latin American societies. Men are said to have higher level of command over business resources, while women are engaged with household activities including rising children and family budget. This situation is reflected in two important county's indices - gender development index (GDI) and gender inequality index (GII) (UNDP, 2015). The gender inequality index include an indicator on the labour market participation rate for women and men; and the gender development index include an indicator on their economic role measured by male and female GNI per capita. Both indices show high gender inequality in Argentina and Peru, with woman taking back seat in economic activities. For example, GNI per capita for women in Argentina is less than half of that for men (14,202 and 30,237 respectively) with slightly better gender relation for Peru (8,040 and 13,977 respectively). Similarly, women have significantly lower level of participation in the labour force - Argentina $47 \%$ and $75 \%$ (respectively for women and men) and in Peru $68.2 \%$ and $84.4 \%$ respectively. This could indicate that although women participate in family businesses, they have less influence on running the business because of their traditional inequality in the economic and business domains.

Another explanation to the fact that no significant gender differences have been found with respect to family business can also be attributed to culture attributes, but with somewhat inverse logic. As asserted by Schmitt et al. (2008), and discussed in the literature review, the personality differences between men and women may vary in different cultural countries, and will be less significant in less modern societies. Accordingly, modern societies which promote gender equality and freedom, increases the manifestation of gender differences. Inversely, in less modern societies such as exists in Argentina and Peru, gender personality differences tend to be reduced, that was reflected in no significant gender difference in this research. Therefore, it could be that a different sample, in particularly modern societies could yield different results.

A competing explanation to the research findings, of no significant gender impact on the performance of family business, can be based on analyzing the sector of small businesses in Argentina and Peru. Most of the family businesses in these countries belong to the sector of small and medium-sized enterprises (SME) (Kaplun, 2001; PWC, 2014). The performance of small businesses is strongly affected by barriers, which can be separated into two categories - external and internal. External barriers are those factors that cannot be influenced directly by the owner of small business, but rather by government institutions that are setting various regulatory conditions as well as financing conditions, state of the economy, and market challenges (Gill and Biger, 2012). Internal barriers are those factors that are highly dependent on the owner-manager, including management and marketing experience (Marom and Lussier, 2014). In Argentina and Peru, the external barriers are extremely high - in Argentina even more than in Peru. According the World Bank 'Doing Business' report, which explores "how easy or difficult it is for a local entrepreneur to open and run a small to medium-size business" [World Bank Doing Business, (2016), p.4]. It is evident that the external barriers to SME are very high in those countries. Argentina is ranked 116 out of 190 countries, and Peru is 
ranked 54. If the external barriers are very high, this could mean that the internal barriers - owner characteristics, have less impact on performance. In this case, gender differences within the family business settings might have little impact on outcomes.

\section{Conclusions and implications}

Like all studies, there are limitations within this research and the need for further research. First, it is possible that different results could be found in cases where the gender factor is not taken as a percentage alone, but rather takes into account the position of women within the business in terms of level (Board, CEO, President, etc.) and function (marketing, finance, operations, etc.). Second, our data was self-reported by the owner-managers of the businesses, which is subjective by nature. Moreover, managers and owners in different cultures may have different interpretations to questions within the research tool even though the questionnaire was pilot tested for understanding.

Considering the findings and the limitations of our research, we suggest the need for future research. First, duplication of this study in other cultures is needed to determine whether gender differences in management of family businesses is culture dependent. Moreover, such future research should explore differences between two distinct cultures - traditional and modern. This could serve to verify the notion that larger gender differences exist in modern societies (Schmitt et al., 2008). Second, future research should verify these findings through a more objective data collection method. One way to achieve this is by collecting data with regard to behaviour and actions rather than self-reported data. A different perspective on gender differences could also be gained by data collection from other stakeholders including business partners as well as employees. Future research could also take a different route by investigating additional mediators such as the size category of the family business and the industry sector of the business.

With the large populations of these two countries and their being historically traditional societies, steps toward the further inclusion of women in the family business sector have the potential to provide further economic regional developmental growth. This research has important regional implications that can contribute to the further development of the economies in Argentina, Peru, and Latin America in general. This region is taking steps, and moving forward, to create further growth following the recession during the first half of the 2010s. This empirical research finding of no significant gender differences in Argentina and Peru that can be characterised as traditional societies, support previous findings by Schmitt et al. (2008). While the two South American countries are making efforts to move forward economically, it should be noted that they are developing based on their traditional culture backgrounds, which tends to impede economic development processes (Costa et al., 2001). Therefore, educators, consultants, and public policy makers can help this region transition from a traditional agricultural society to a modern society to aid in sustainable economy growth.

An important measure that can be taken to create economic growth is to implement public policy that creates more family businesses. Given the findings of this research, that women are as capable as men to start and lead family businesses, and with the growth of women owned and managed businesses globally, educators, consultants, and public policy makers should make these findings known to help transition from a traditional to a modern society. Awareness of these findings can encourage more women to create and manage more businesses. Educators, consultants, and public policy makers can also make 
men and women would be entrepreneurs aware that the United States Small Business Administration (SBA) has free online resources available to anyone globally at www.sba.gov. They can help them use this free online resource and use this knowledge to launch and grow new ventures. The SBA also provides specific resources for women entrepreneurs.

In addition to knowledge, encouragement, and free SBA resources, South American governments can provide support to aid more men and women to start new ventures and grow their businesses. Public policy makers can implement some of the general United States Small Business Administration (SBA) programmes such as loan programmes, how to start a business, writing business plans, prepare proposals for government contract, and growing an established company (SBA, 2015).

More specifically, the SBA provides resources to help women entrepreneurs launch new businesses, grow their businesses and compete in the global marketplace. SBA resources available to USA women that can be adapted by other public policy makers include:

1 SBA's Office of Women's Business Ownership (answers questions on the Women's Business Center programme or other services for women),

2 SBA's Women's Business Centers (over 100 centres assist women in starting and growing small businesses),

3 SBA's Women-Owned Federal Contracting Program (helps women compete for federal contracting business opportunities),

4 SBA Loans (offers women a variety of loan programmes for specific purposes).

Implications from the findings of this current research study also support the need for 'theory into practice'. With a continuing and developing understanding of gender issues in family business, owner-managers of family businesses, and consultants and advisors to family businesses, can better understand whether any of a family firm's managerial activities might be impacted by the owner-managers' gender. As an example, the findings of this current study would imply to an owner-manager that most of his or her managerial activities are likely to be unaffected by his or her gender and that his or her managerial focus should simply be on performing as effectively as possible.

And because the results of earlier research studies have been mixed, clear conclusions regarding gender-based managerial similarities and differences in family firms remain elusive. Thus, this study provides a theoretical contribution to our understanding of gender issues in family business management by largely supporting development of a theory that there are no significant differences between the behaviour of male and female family business owner-managers.

\section{References}

Adams, R.B. and Funk, P. (2012) 'Beyond the glass ceiling: does gender matter?', Management Science, Vol. 58, No. 2, pp.219-235.

Al-Dajani, H., Bika, Z., Collins, L. and Swail, J. (2014) 'Gender and family business: new theoretical directions', International Journal of Gender and Entrepreneurship, Vol. 6, No. 3, pp.218-230. 
Amin, M. (2011) 'Labor productivity, firm-size and gender: the case of informal firms in Argentina and Peru', World Bank Group, Enterprise Note No. 22. 2011, [online] https://www.enterprisesurveys.org/ /media/GIAWB/EnterpriseSurveys/Documents/Enterprise Notes/Gender-22.pdf (accessed July 2016).

APEC - Asia-Pacific Economic Cooperation (2016) 'Women's economic participation in Peru', US-ATAARI Peru Gender Assessment (final), [online] http://www.nathaninc.com/ sites/default/files/US-ATAARI\%20Peru\%20Gender\%20Assessment\%20(final).pdf (accessed August 2016).

Astrachan, J. (2002) ‘Editor's notes’, Family Business Review, Vol. 15, No. 1, pp.v-vii.

Astrachan, J. and Shanker, M. (2003) 'Family businesses' contribution to the US economy: a closer look', Family Business Review, Vol. 16, No. 3, pp.211-219.

Bennett, R. and Dann, S. (2000) 'The changing experience of Australian female entrepreneurs', Gender, Work and Organization, Vol. 7, No. 2, pp.75-83.

Bellet, W., Dunn, B., Heck, R.K., Parady, P., Powell, J. and Upton, N. (1995) 'Family business as a field of study' [online] http://www.fambiz.com/Orgs/Cornell/articles/real/ifbpa.cfm.

Bird, B., Welsch, H., Astrachan, J.H. and Pistrui, D. (2002) 'Family business research: the evolution of an academic field', Family Business Review, Vol. 15, No. 4, pp.337-350.

Brewer, N., Mitchell, P. and Weber, N. (2002) 'Gender role, organizational status, and conflict management styles', International Journal of Conflict Management, Vol. 13, No. 1, pp.78-94.

Bureau of Labor Statistics (2015) 'Women in the labor force: a databook', U.S. Bureau of Labor Statistics, BLS Reports, December.

Buss, D.M. (1997) 'Evolutionary foundations of personality', in Hogan, R. (Ed.), Handbook of Personality Psychology, pp.317-344, Academic Press, London.

Buss, D.M. and Schmitt, D.P. (2011) 'Evolutionary psychology and feminism', Sex Roles, Vol. 64, No. 9-10, pp.768-787.

Bussey, K. and Bandura, A. (1999) 'Social cognitive theory of gender development and differentiation', Psychological Review, Vol. 106, No. 4, p.676.

Carsrud, A. (1994) Lessons Learned in Creating a Family Business Program, unpublished manuscript, University of California, Los Angeles.

Carter, N., Williams, M. and Reynolds, P. (1997) 'Discontinuance among new firms in retail: the influence of initial resources, strategy, and gender', Journal of Business Venturing, Vol. 12, No. 2, pp.125-145.

Chaganti, R. and Parasuraman, S. (1996) 'A study of the impacts of gender on business performance and management patterns in small business', Entrepreneurship Theory and Practice, Vol. 21, No. 2, pp.73-75.

Cole, P.M. (1997) 'Women in family business', Family Business Review, Vol. 10, No. 4, pp.353-371.

Collerette, P. and Aubry, P. (1990) 'Socio-economic evolution of women business owners in Quebec (1987)', Journal of Business Ethics, Vol. 9, No. 45, pp.417-422.

Collins-Dodd, C., Gordon, I. and Smart, C. (2004) 'Further evidence on the role of gender in financial performance', Journal of Small Business Management, Vol. 42, No. 4, pp.395-417.

Costa Jr. P., Terracciano, A. and McCrae, R.R. (2001) 'Gender differences in personality traits across cultures: robust and surprising findings', Journal of Personality and Social Psychology, Vol. 81, No. 2, p.322.

Danes, S.M., Haberman, H. and McTavish, D. (2005) 'Gendered discourse about family business', Family Relations, Vol. 54, No. 1, pp.116-130.

Danes, S.M. and Olson, P.D. (2003) 'Women's role involvement in family businesses, business tensions, and business success', Family Business Review, Vol. 16, No. 1, pp.53-68.

Danes, S.M., Stafford, K. and Loy, J.T.L. (2007) 'Family business performance: the effects of gender and management', Journal of Business Research, Vol. 60, No. 10, pp.1058-1069. 
Danes, S.M., Stafford, K., Haynes, G. and Amarapurkar, S.S. (2009) 'Family capital of family firms: bridging human, social, and financial capita', Family Business Review, Vol. 22, pp.199-216.

Dennis Jr., W.J. (2003) 'Raising response rates in mail surveys of small business owners: results of an experiment', Journal of Small Business Management, Vol. 41, No. 3, pp.278-295.

D’Annunzio, M.C. and Rábago, P.L. (2007) 'Entrepreneurship, instituciones y turismo: una combinación para la generación de entornos innovadores', XII Reunión Anual RedPyMes., Campinas. Brasil.

DiBerardinis, J., Ramage, K. and Levitt, S. (1984) 'Risky shift and gender of the advocate: information theory versus normative theory', Group and Organization Management, Vol. 9, No. 2, pp.189-200.

Eagly, A.H. (1987) Sex Differences in Social Behavior: A Social-role Interpretation, Erlbaum, Hillsdale, NJ.

Eagly, A.H. (2013) Sex Differences in Social Behavior: A Social-role Interpretation, Psychology Press.

Eagly, A.H. and Carli, L.L. (2003) 'The female leadership advantage: an evaluation of the evidence', The Leadership Quarterly, Vol. 14, No. 6, pp.807-834.

Eagly, A.H. and Carli, L.L. (2007) 'Women and the labyrinth of leadership', Harvard business Review, Vol. 85, No. 9, p.62.

Eagly, A.H. and Heilman, M.E. (2016) 'Gender and leadership: introduction to the special issue', The Leadership Quarterly, Vol. 3, No. 2, pp.349-353.

Eagly, A.H. and Johannesen-Schmidt, M.C. (2001) 'The leadership styles of women and men', Journal of Social Issues, Vol. 57, No. 4, pp.781-797.

Eagly, A.H. and Wood, W. (1991) 'Explaining sex differences in social behavior: a meta-analytic perspective', Personality and Social Psychology Bulletin, Vol. 17, No. 3, pp.306-315.

Eagly, A.H. and Wood, W. (1999) 'The origins of sex differences in human behavior: evolved dispositions versus social roles', American Psychologist, Vol. 54, No. 6, p.408.

Eagly, A.H., Wood, W. and Diekman, A.B. (2000) 'Social role theory of sex differences and similarities: a current appraisal', The Developmental Social Psychology of Gender, pp.123-174.

Eals, M. and Silverman, I. (1994) 'The hunter-gatherer theory of spatial sex differences: proximate factors mediating the female advantage in recall of object arrays', Ethology and Sociobiology, Vol. 15, No. 2, pp.95-105.

EY (2014) Family Business Yearbook 2014, Report by business consultancy EY.

EY (2015) Women in Leadership: The Family Business Advantage, Report by business consultancy EY and Georgia's Kennesaw State University, June.

Fasci, M. and Valdez, J. (1998) 'A performance contrast of male- and female-owned small accounting practices', Journal of Small Business Management, Vol. 36, No. 3, pp.1-7.

Filipsson, M., Ljunggren, L. and Oberg, T. (2014) 'Gender differences in risk management of contaminated land at a Swedish authority', Journal of Risk Research, Vol. 17, No. 3, pp.353-365.

Gill, A. and Biger, N. (2012) 'Barriers to small business growth in Canada', Journal of Small Business and Enterprise Development, Vol. 19, No. 4, pp.656-668.

Harveston, P.D., Davis, P.S. and Lyden, J.A. (1997) 'Succession planning in family business: the impact of owner gender', Family Business Review, Vol. 10, No. 4, pp.373-396.

Havenga, W. (2008) 'Gender and age differences in conflict management within small businesses', SA Journal of Human Resource Management, Vol. 6, No. 1, pp.22-28.

Heinonen, J. and Stenholm, P. (2011) 'The contribution of women in family business', International Journal of Entrepreneurship and Innovation Management, Vol. 13, No. 1, pp.62-79. 
IMF (2015) 'World economic outlook: adjusting to lower commodity prices', October, [online] http://www.imf.org/external/pubs/ft/weo/2015/02/pdf/text.pdf (accessed July 2016).

IMF (2016) 'Peru: concluding statement of the IMF 2016', Article IV Consultation Mission, 13 June, [online] http://www.imf.org/external/np/ms/2016/061316.htm (accessed July 2016).

Jimenez, R.M. (2009) 'Research on women in family firms current status and future directions', Family Business Review, Vol. 22, No. 1, pp.53-64.

Kaplun, C. (2001) 'Continuidad y cambio: la familia en la empresa', Revista Mercado, Editorial Coyuntura, [online] http://www.mercado.com.ar/nota.php?id=36592 (accesed 18 July 2010).

Kellermanns, F. W., Eddleston, K. A., Barnett, T. and Pearson, A. (2008) 'An exploratory study of family member characteristics and involvement: effects on entrepreneurial behavior in the family firm', Family Business Review, Vol. 21. No. 1, pp.1-14.

Kets de Vries, M. (1993) 'The dynamics of family controlled firms: the good and bad news', Organizational Dynamics, Vol. 21, No. 3, pp.59-71.

Kotey, B. and Sheridan, A. (2001) 'Gender and the practice of HRM in small business', Asia Pacific Journal of Human Resources, Vol. 39, No. 3, pp.23-40.

Kraus, S., Harms, R. and Fink, M. (2011) 'Family firm research: sketching a research field', International Journal of Entrepreneurship and Innovation Management, Vol. 13, No. 1, pp.32-47.

Lasagni, A. (2012) 'How can external relationships enhance innovation in SMEs? New evidence for Europe', Journal of Small Business Management, Vol. 50, No. 2, pp.310-339.

Liff, S. and Ward, K. (2001) 'Distorted views through the glass ceiling: the construction of women's understandings of promotion and senior management positions', Gender, Work \& Organization, Vol. 8, No. 1, pp.19-36.

Lin, N. (2000) 'Inequality in social capital', Contemporary Sociology, Vol. 29, No. 6, pp.785-795.

Lussier, R.N. (1997) 'Predicting entrepreneurial success versus failure: a comparison of multi and single-industry techniques', Academy of Entrepreneurship Journal, Vol. 3, No. 1, pp.89-101.

Lussier, R.N. (2011) Research Methods and Statistics for Business, Waveland, Long Grove, IL.

Maccoby, E.E. and Jacklin, C.N. (1974) The Psychology of Sex Differences, Vol. 1, Stanford University Press, Palo Alto, CA.

Mancuso, E. (2009) 'La empresa familiar emprendedora', Universidad de Palermo GSB, Conferencia Endeavor.

Mantyla, T. (2013) 'Gender differences in multitasking reflect spatial ability', Psychological Science, Vol. 2013, No. 24, pp.514-520.

Marom, S., and Lussier, R.N. (2014) 'A business success versus failure prediction model for small businesses in Israel', Business and Economic Research, Vol. 4, No. 2, pp.63-81.

McCann, J., Leon-Guerrero, A. and Haley, J. (1997) 'Family business with a capital "B:" characteristics, priorities and performance of family firms', Paper presented at the Academy of Management Meeting, Boston, MA.

Miller, D., Le Breton-Miller, I., Lester, R.H. and Cannella, A.A. (2007) 'Are family firms really superior performers?', Journal of Corporate Finance, Vol. 13, No. 5, pp.829-858.

Mínguez-Vera, A. and Martin, A. (2011) 'Gender and management on Spanish SMEs: an empirical analysis', The International Journal of Human Resource Management, Vol. 22, No. 14, pp.2852-2873.

Morck, R. and Yeung, B. (2003) 'Agency problems in large family business groups', Entrepreneurship: Theory and Practice, Vol. 27, No. 4, pp.367-382.

Morris, M.H., Williams, R.O., Allen, J.A. and Avila, R.A. (1997) 'Correlates of success in family business transitions', Journal of Business Venturing, Vol. 12, No. 5, pp.385-401.

Nelton, S. (1998) 'The rise of women in family firms: a call for research now', Family Business Review, Vol. 11, No. 3, pp.215-218. 
Niethardt, E. (2007) 'La empresa familiar convive con la globalización', [online] http://www.niethardt.com/publicaciones.php (accessed 18 July 18 2010).

Powell, G.N. (1990) 'One more time: do female and male managers differ?', The Executive, Vol. 4, No. 3, pp.68-75.

Powell, M. and Ansic, D. (1997) 'Gender differences in risk behavior in financial decision-making: an experimental analysis', Journal of Economic Psychology, Vol. 18, No. 6, pp.605-628.

Poza, E. (2007) Family Business, South-Western/Cengage, Mason, OH.

Poza, E.J. and Daugherty, M. (2013) Family Business, Cengage Learning, Boston, MA.

PWC (2014) Up Close and Professional: the Family Factor Global Family Business Survey, Price Waterhouse Coopers [online] http://www.pwc.com/familybusinesssurvey (accessed July 2016).

Rábago, P.L., D’Annunzio M.C., Monserrat S. and Barberón, S. (2009) 'Empresas familiares: caracterización e identificación de problemáticas específicas', VI Encuentro de Centros de Investigación, Tandil, Universidad Nacional del Centro de la Provincia de Buenos Aires. ISBN N $978-950-658-235-7$.

Reay, T. and Whetten, D. (2011) 'What constitutes a theoretical contribution in family business?', Family Business Review, Vol. 24, No. 2, pp.105-110.

Ren, D., Zhou, H. and Fu, X. (2009) 'A deeper look at gender difference in multitasking: gender-specific mechanism of cognitive control', in 2009 Fifth International Conference on Natural Computation, Vol. 5, pp.13-17, IEEE.

Renzulli, L.A., Aldrich, H. and Moody, J. (2000) 'Family matters: gender, networks, and entrepreneurial outcomes', Social Forces, Vol. 79, No. 2, pp.523-546.

Rottenberg, D. (2002) 'The oldest family businesses', Family Business Magazine, Vol. 13, No. 1, pp.44-57.

Rowe, B. and Hong, G. (2000) 'The role of wives in family businesses: the paid and unpaid work of women', Family Business Review, Vol. 13, No. 1, pp.1-13.

Ruderman, M.N., Ohlott, P.J., Panzer, K. and King, S.N. (2002) 'Benefits of multiple roles for managerial women', Academy of management Journal, Vol. 45, No. 2, pp.369-386.

Schmitt, D.P., Realo, A., Voracek, M. and Allik, J. (2008) 'Why can't a man be more like a woman? Sex differences in big five personality traits across 55 cultures', Journal of Personality and Social Psychology, Vol. 94, No. 1, p.168.

Sciascia, S. and Mazzola, P. (2008) 'Family involvement in ownership and management: exploring nonlinear effects on performance', Family Business Review, Vol. 21, No. 4, pp.331-345.

Sharma, P., Chrisman, J.J. and Gersick, K.E. (2012) '25 years of family business review: reflections on the past and perspectives for the future', Family Business Review, Vol. 25, No. 1 , p.5.

Shimizu, T. (2004) Family Business in Peru, Institute of Developing Economies, JETRO, IDE Discussion Paper. No. 7. 2004.8. http://hdl.handle.net/2344/197 (accessed July 2016).

Silverman, I., Choi, J. and Peters, M. (2007) 'The hunter-gatherer theory of sex differences in spatial abilities: data from 40 countries', Archives of Sexual Behavior, Vol. 36, No. 2, pp.261-268.

Small Business Administration - SBA (2015) Resource Guide for Small Business, Fall, [online] https://www.sba.gov/sites/default/files/files/resourceguide_national.pdf and Women Owned Businesses, [online] https://www.sba.gov/starting-business/how-start-business/businesstypes/women-owned-businesses (accessed July 2016).

Smith, M. (2007) 'Women take charge of more family companies but face added hurdles', Family Business, Autumn, pp.1-2, Caledonian Family Business Centre, UK.

Sonfield, M.C. and Lussier, R.N. (2004) 'First, second and third-generation family firms: a comparison', Family Business Review, Vol. 17, No. 3, pp.189-202. 
Sonfield, M.C. and Lussier, R.N. (2009) 'Gender in family business ownership and management: a six-country analysis', International Journal of Gender and Entrepreneurship, Vol. 1, No. 2, pp.96-117.

Sonfield, M.C. and Lussier, R.N. (2012) 'Gender in family business management: a multinational analysis', Journal of Family Business Management, Vol. 2, No. 2, pp.110-129.

Sonfield, M., Lussier, R. Corman, J. and McKinney, M. (2001) 'Gender comparisons in strategic decision-making: an empirical analysis of the entrepreneurial strategy matrix', Journal of Small Business Management, Vol. 39, No. 2, pp.55-63.

Sorenson, R.L. and Bierman, L. (2009) 'Family capital, family business, and free enterprise', Family Business Review, Vol. 22, No. 3, pp.193-195.

The Economist (2015) 'Latin America's economies: a slow road to recovery', [online] http://www.economist.com/news/finance-and-economics/21672328-slow-road-recovery-greydays (10 October 2015).

Vadnjal, J. and Zupan, B. (2009) 'The role of women in family businesses', Economic and Business Review for Central and South-Eastern Europe, Vol. 11, No. 2, p.159.

Vera, C.F. and Dean, M.A. (2005) 'An examination of the challenges daughters face in family business succession', Family Business Review, Vol. 18, No. 4, pp.321-346.

UNDP (2015) UN Human Development Report 2015.

UN HDR (2015) UN Human Development Report 2014, [online] http:/hdr.undp.org/sites/ default/files/2015_human_development_report.pdf (accessed July 2016).

Wagner, J. (2007) 'What a difference a Y makes - female and male nascent entrepreneurs in Germany', Small Business Economics, Vol. 28, No. 1, pp.1-21.

Watson, J. (2001) 'Examining the impact on performance of demographic differences between male and female controlled SMEs', Small Enterprise Research, Vol. 9, No. 2, pp.55-70.

Watson, J. (2002) 'Comparing the performance of male- and female-controlled businesses: relating outputs to inputs', Entrepreneurship Theory and Practice, Vol. 26, No. 3, pp.91-100.

Westermann, O., Ashby, J. and Pretty, J. (2005) 'Gender and social capital: the importance of gender differences for the maturity and effectiveness of natural resource management groups', World Development, Vol. 33, No. 11, pp.1783-1799.

Wood, W. and Eagly, A.H. (2002) 'A cross-cultural analysis of the behavior of women and men: implications for the origins of sex differences', Psychological Bulletin, Vol. 128, No. 5, pp.699-727.

World Economic Forum (2014) The Global Gender Gap Report 2014, World Economic Forum, Geneva, Switzerland.

World Bank (2015a) 'Latin America and the rising south: changing world, changing priorities', Latin America and Caribbean Studies, [online] https://openknowledge.worldbank.org/handle/ 10986/21869 (accessed July 2016).

World Bank (2015b) Argentina, [online] http://data.worldbank.org/country/argentina (accessed July 2016).

World Bank (2015c) Peru, [online] http://data.worldbank.org/country/peru (accessed July 2016).

World Economic Forum (2016) 'Five things to know about Latin America's economy', [online] https://www.weforum.org/agenda/2016/01/5-things-to-know-about-latin-america-s-economy/ (accessed 19 January 2016).

World Bank (2016) Doing Business in Peru, Doing Business 2016: Measuring regulatory quality and efficiency. 